\title{
A Review of the Application of Biofloccualnts in Wastewater Treatment
}

\author{
Mayowa O. Agunbiade ${ }^{1,2}$, Carolina H. Pohl' ${ }^{2}$ Anofi O.T. Ashafa ${ }^{1}$ \\ ${ }^{1}$ Phytomedicine and Phytopharmacology Research Group, Department of Plant Sciences, University of the Free Sate, \\ Qwaqwa Campus, Puthaditjabha 9866, South Africa \\ ${ }^{2}$ Department of Microbial, Biochemical and Food Biotechnology, University of the Free State, \\ Bloemfontein 9301, South Africa
}

Received: 14 October 2015

Accepted: 19 December 2015

\begin{abstract}
The rate of increase in industrialization and daily human activities has resulted in a tremendous increase in the amounts of waste and wastewater containing organic and inorganic pollutants discharged to the environment. Coagulation-flocculation technology has been widely employed in water/wastewater treatment as a convenient and reliable technique for removing colloids, particles, and cell debris. Organic and inorganic flocculants have also been used in fermentation industries, and in waste and water treatment due to its potential to flocculate efficiently at a minute dosage. However, their use has been restricted as a result of their low efficiency, associated health risks, and non-biodegradability. As a result, the health implication of chemical flocculants has necessitated environmentally friendly biodegradable bioflocculants in wastewater treatment in terms of dye, colour, solids, and turbidity removal. Industrial applications of some microorganisms implicated in bioflocculation have been established. However, the application of actinobacteria strains that have been isolated, screened, and confirmed for bioflocculation have yet to be validated. Hence, this paper reiterates that Actinobacteria have been implicated in flocculation and elaborates on the need for isolation and screening of novel Actinomycetes with better removal and cost efficiency in order to enhance their large- and medium-scale production and establish their industrial application.
\end{abstract}

Keywords: bioflocculants, coagulation-flocculation, actinobacteria, wastewater treatment, application

\section{Introduction}

Flocculation is an essential parameter employed for the removal of suspended solids in domestic and industrial wastewater treatment. Flocculation is accomplished with the help of flocculants, which are either natural or synthetic substances that facilitate the aggregation of particles to form flocs. Flocculation has attracted wide attention as a

*e-mail: ashafaaot@ufs.ac.za means of separation technique in portable, domestic, and industrial wastewater treatment plants. Flocculants have been employed in the recovery of suspended solutes from solution [1]. The use of flocculants in raw water treatment, surface treatment, industry, petroleum refinery effluent, and the paper industry has been well documented [2].

The coagulation-flocculation approach is widely used in water and wastewater treatments. Also, flocculation has been a known factor in the removal or separation of colloids and suspended particles of natural organic matter, and metal ions. Additional applications of flocculating agents 
include the elimination of toxic metals, anions, color, and odour in wastewater treatment. The use of chemically synthesized flocculating agents such as aluminum sulfate, polyaluminum chloride, and ferric chloride, and polymers like polyacrylamide derivatives have been frequently employed in wastewater treatment and fermentation industries as a result of their cost effectiveness and strong flocculating efficiency. However, the application of inorganic and organic flocculating agents has been drastically reduced due to the fact that large quantities are required to achieve effective flocculation. The commonly used organic flocculants are polyacrylamide, polyacrylic acid, poly (diallyl dimethyl ammonium chloride), and polyamine [3]. Flocculation efficiency is usually measured or quantified based on turbidity removal, chemical oxygen demand, and colour removal.

Bioflocculation is the process whereby stable aggregates are formed by extracellular polymers produced by living cells. Recently, the use of microbial flocculants has become a promising substitute for chemical flocculants because of their safety and biodegradability efficiency, which have put them in high demand [4].

Bioflocculants and metal ions have played an equally tremendous role in forming and settling sludge in anaerobic and aerobic treatment systems [5]. In addition, they can serve as an alternative to centrifugation and filtration for harvesting microbial cells from broth in the food and fermentation industries [6]. Since bioflocculants are generally biodegradable in nature, their use in wastewater treatment, downstream processing, and fermentation processes have increased [7]. The choice of adopting biotechnological methods for the production of bioflocculants solely depends on the possibility of using different microorganisms to synthesize extracellular substances with different compositions. In recent years, it has been documented that many microorganisms such as actinomycetes, fungi, bacteria, and algae have the ability to produce environmentally safe extracellular polymers that act as bioflocculants [8]. On the contrary, according to literature, researchers have proved the use of some chemically synthetic flocculant substances to be detrimental to aquatic life and the environment. For instance, acrylamide monomer, which is non-degradable, has been implicated in causing cancer and Alzheimer's disease [9]. Hence, there is a need to substitute or replace the exploration of synthetic flocculants with bioflocculants produced by microorganisms.

Also, an outstanding economic factor is that many developing countries can hardly afford the high costs of purchasing imported chemicals for water and wastewater treatment. This has therefore necessitated the exploration of new microorganisms that could produce flocculants with high flocculating activity and optimizing their fermentation processes in order to improve productivity. Bioflocculants have been used to treat waste and industrial water as both pure and mixed cultures. Microbial flocculants have also been implicated in the adsorption of heavy metals [10]. Also, the bioflocculant produced by Serratia ficaria was able to remove COD and turbidity at efficiencies of $64.1-80.7 \%$ and $91.8-93.7 \%$, respectively, in agricultural wastewater [11]. In addition, bioflocculant MMF1 was reported by [12] in removing COD in indigotin printing and dyeing wastewater.

On the other hand, turbidity and COD removal from swine wastewater were achieved at flocculating efficiencies of $91 \%$ and $42 \%$, respectively, when treated with bioflocculant $(x n 11+x n 7)$ [13]. The biofloculant produced by the mixed culture of Halobacillus $s p$. mvuyo and Oceanobacillus sp. pinky exhibited a significant efficiency when tested on waste and river waters [14]. Their findings confirmed that the consortium of the mixed bioflocculant eliminates COD and turbidity in

Table 1. Applications of Some Bioflocculants Producing Microorganisms.

\begin{tabular}{|c|c|c|c|}
\hline Application & Microorganism & Remarks & Reference \\
\hline \multirow{3}{*}{$\begin{array}{l}\text { Biomass recovery } \\
\text { and cell removal }\end{array}$} & Paenibacillus polymyxa & Removed Scenedesmus sp. & [1] \\
\hline & Solibacillus silvestris & Removed Nannochloropsis oceanica & {$[17]$} \\
\hline & Klebsiella pneumoniae & Removed Acanthamoeba cysts & {$[18]$} \\
\hline \multirow{3}{*}{$\begin{array}{c}\text { Water and } \\
\text { wastewater treatment }\end{array}$} & Oceanobacillus and Halobacillus & Treated brewery, dairy wastewater, and river water & {$[14]$} \\
\hline & Azotobacter indicus & $\begin{array}{l}\text { Treated dairy, wool, starch, and sugar industries } \\
\text { wastewater }\end{array}$ & {$[1]$} \\
\hline & Cobetia sp. and Bacillus sp. & Treated river water, dairy, and brewery wastewater & {$[19]$} \\
\hline \multirow{3}{*}{ Decolorization } & Rhodococcus erythropolis & Remove disperse dye solutions & {$[20]$} \\
\hline & Serratia ficaria & Decolourized pulp effluent & {$[10]$} \\
\hline & Chryseomonas luteola & Decolourized dye wastewater & {$[21]$} \\
\hline \multirow{3}{*}{$\begin{array}{l}\text { Mining and other } \\
\text { applications }\end{array}$} & Rhodopseudomonas sphaeroides & Flocculated coal slurry & {$[22]$} \\
\hline & Bacillus subtilis & Synthesis of Ag nanoparticles $(60 \mathrm{~nm})$ & {$[23]$} \\
\hline & Halomonas Maura & $\begin{array}{l}\text { Synthesis of mauran/chitosan nanopareticles } \\
\qquad(30-200 \mathrm{~nm})\end{array}$ & [24] \\
\hline
\end{tabular}


brewery wastewater, dairy wastewater, and river water at efficiencies greater than $90 \%$ when compared with polyacrylamide and aluminum chloride, which are used as conventional flocculants. [14]. Based on literature, fungi, bacteria, and algae have been greatly implicated in flocculation and in treatment of waste and industrial waters $[15,16]$. However, actinomycetes also have been employed in flocculation, but their production on a large scale medium and application in treating waste and industrial waters has yet to be established.

In this paper we reviewed Actinobacteria, which has been implicated in flocculation, and elaborate on the need for isolation and screening of novel Actinomycetes with better removal and cost efficiency that will exhibit the potential of treating both waste and industrial waters. Some of the reported microorganisms that have been implicated in flocculation and their industrial applications are summarized in Table 1.

Literature has affirmed that actinobacteria have been isolated, screened, and implicated in flocculation. However, their industrial applications have yet to be established $[25,26,27,28,29,30,31]$. The genera of Actinobacteria that has been implicated in flocculation are: the genus Arthrobacter [25, 26], the genus Actinobacterium [27], the genus Brachybacterium [28], the genus Streptomyces $[29,30]$, and the genus Nocardiopsis [31]. Their Culture conditions and flocculating efficiencies are summarized in Table 2.

Culture conditions have played an immense role in bioflocculant production. Researchers have confirmed that carbon and nitrogen source requirement varies with different isolates [32, 7]. Considering the table above, nitrogen and carbon sources required by each actinobacteria differ from each strain, and this parameter is one of the determining factors in bioflocculant production. Furthermore, researchers have confirmed that bioflocculant-producing bacteria thrive in a medium that contains organic carbon. For instance, [25] reported that Arthrobacter sp uses lactose, glucose, and urea as the best carbon and nitrogen substrates for optimum flocculating efficiency. Based on the table above, each actinobacterium has attained its optimum flocculating efficiency with different carbon and nitrogen substrates.
Initial $\mathrm{pH}$ is also one of the major parameters that influence bioflocculant production and flocculating activity. Salehizadeh and Shojaosadati [7] reported that initial $\mathrm{pH}$ of medium depicts the electric charge of cells and oxidation reduction capability, which may hinder or support the adsorption of nutrients and enzymatic reactions in different organisms. Wang et al. [33] has reported that cations enhanced or facilitated initial adsorption of flocculants in suspended colloids/particles by a means of reducing or minimizing the negative charge on polymers and colloids.

Cations have aided flocculation in actinobacteria by neutralizing and stabilizing the negative charge of some functional groups, thereby resulting in bridge formation between colloids [7]. The addition of cations to suspension or particles stimulates the rate of floc formation, thereby resulting in sedimentation of particles.

\section{Isolation of Actinobacteria on Cultivation Media}

Actinomycetes have been isolated from both soil sediment and water samples using a serial dilution spread plate technique. These organisms thrive well on mostly selective media such as starch casein agar, glucose yeast malt extract agar, actinomycetes isolation media, soil extract agar, glycerol-asparagine agar, colloidal chitin, and M3 agar [34]. Antibiotics such as cyclohexamide, nalidixic acid, nystatin, rifampicin, and fluconazole are usually employed to supplement the media in order to inhibit the growth of other bacteria and fungi.

\section{Identification of Actinomycetes}

The concept of characterizing actinomycetes to genus level has been validated by [35] and Goodfellow [36] using a combination of cultural, morphological, and chemical properties. Conversely, characterization of these bacteria to specie level is more cumbersome. The availability of gene sequencing has revolutionized the taxonomy of the aerobic actinomycetes and has become an important yardstick for the identification and characterization of

Table 2. Culture Conditions and Flocculating Efficiencies of Actinobacteria Spp Implicated in Flocculation.

\begin{tabular}{|c|c|c|c|c|}
\hline Isolate & Culture conditions & Component & F/A & References \\
\hline Arthrobacter sp Raats & Lactose, urea, glucose, $\mathrm{Mg}^{2+}$, and $\mathrm{pH} 7.0$ & Glycoprotein & $84 \%$ & {$[25,26]$} \\
\hline Actinobacterium sp Mayor & $\begin{array}{c}\text { Sodium carbonate, Ammonium, sulfate, urea, } \\
\text { yeast extract, } \mathrm{Ca}^{2+}, \text { and } \mathrm{pH} 8.0\end{array}$ & Polysaccharide & $91 \%$ & {$[27]$} \\
\hline Brachybacterium $\mathrm{sp}$ & Maltose, urea $\mathrm{MgCl}_{2}$, and $\mathrm{pH} 7.2$ & Glycosaminoglycan & $91.17 \%$ & {$[28]$} \\
\hline Streptomyces sp & Glucose, ammonium sulfate, $\mathrm{MgCl}_{2}$, and $\mathrm{pH} 6.8$ & Proteoglycan & $89 \%$ & {$[29]$} \\
\hline Nocardiopsis aegyptia sp. nov & Glucose, peptone, $\mathrm{CaCl}_{2}$, and $\mathrm{pH} 7.0$ & Polysaccharide & $89 \%$ & {$[30]$} \\
\hline Streptomyces grieseus & Yeast extract and $\mathrm{pH} 7.0$ & NA & NA & {$[31]$} \\
\hline
\end{tabular}

F/A: Flocculating activity

NA: Not applicable 
clinical isolates. The 16S rRNA gene sequencing has been employed to identify diversity of actinomycetes, which corroborates the method of chemical and morphological taxonomy.

\section{Actinobacteria}

Actinomycetes are gram-positive, aerobic, and mycelial prokaryote organisms with a high guanine:cytosine ratio [37]. They are unicellular organisms and their means of reproduction is by special spores, fission, or conidia. Most are free-living saprophytic bacteria found widely distributed in soil and water [38]. They resemble fungi morphologically and bacteria physiologically [39].

They are related to true bacteria in terms of classification, but they are generally considered as higher filamentous bacteria [40]. Actinomycetes from the genus Streptomyces account for two thirds of antibiotic production while the genus Micromonospora takes second place. Vobis [41] reported that Micromonospora produced a wide range of broad-spectrum antibiotic substances. The genera Micromonospora and Streptomyces are widely and evenly distributed in aquatic ecosystems and are largely more abundant than other groups of actinomycetes [42].

The genera Actinomadura, Actinoplanes, Actinosynnema, Dactylosporangium, Kibdelosporangium, Kitasatosporia, Microbisporia, Micromonospotra, Nocardia, Saccharopolyspora, Streptoalloteichus, Streptosporangium, and Streptoverticillium have also being implicated in antibiotic production [43].

Literature has revealed that ecology of this bacterium is not well documented. Actinomycetes are found in many aquatic environments. They have been isolated from marine and freshwater bodies [44, 45,]. The most common actinomycetes isolated from freshwater environments include Actinoplanes, Micromonospora, Rhodococcus, Streptomyces, and Thermoactinomyces [46].

\section{The Genus Streptomyces}

This is the largest group of Actinobacteria and it belongs to the family Streptomycetaceae. [47]. Streptomycetaceae is a family of Actinobacteria, which constitute the monotypic suborder Streptomycineae. Streptomyces are grampositive, aerobic, spore-forming microorganism found mostly in soil sediment and marine environments. Goodfellow and Williams [48] reported that they possess highly branched substrate and aerial mycelium, spores on aerial mycelium, and occasionally on substrate medium. Currently, 600 species and 38 subspecies of Streptomyces bacteria have been described. The most unique attribute of Streptomyces is the ability to produce secondary metabolites and bioactive compounds that are important in human and veterinary medicine, and in agriculture [49]. The genus Streptomyces has served as a basic source of many antibiotics, namely streptomycin, and this was the first antibiotic produced against tuberculosis. They have been implicated in the production of natural-based antibiotics, which includes cypemycin, grisemycin, bottro mycins, and chloramphenicol [50].

\section{The genus Arthrobacter}

The genus Arthrobacter belongs to the Micrococcaceae family. Based on the quinone system and peptidoglycan structure, the genus Arthrobacter can be subdivided into two groups. Arthrobacter is a bacteria usually found in soil, and some have been recovered from clinical specimens. They are non-sporulating, gram-positive, and obligate aerobes that show respiratory metabolism with the exception of Arthrobacter globiformis and Arthrobacter nicotianae, which are attributed with anaerobic metabolism [51]. Based on their unique metabolic diversity, Arthrobacter species have been explored in industrial applications in the treatment of contaminated wastewater [52]. Arthrobacter nitroguajacolicus has been reported as a strain with the ability to transform acrylonitrile into acrylic acid [53]. Arthrobacter crystallopoietes has been implicated in the reduction of hexavalent chromium in contaminated soil, indicating its biotechnological role in bioremediation [54].

\section{The genus Nocardiopsis}

The genus Nocardiopsis are aerobic, spore-forming actinomycetes that are known for the production of branched, vegetative mycelium and aerial hyphae. Species of the genus Nocardiopsis may be characterized based on the color of their mature aerial and substrate mycelia, their ability to break down different compounds, and their ability to utilize different carbon sources [55]. The genus Nocardiopsis has been currently divided into seven distinct species: Nocardiopsis alborubidus, Nocardiopsis albus, Nocardiopsis antarcticus, Nocardiopsis dassonvillei, Nocardiopsis halophila, Nocardiopsis listen, and Nocardiopsis lucentensis. Nocardiopsis albus includes two subspecies, Nocardiopsis albus subsp. albus and Nocardiopsis albus subsp. prasina. Nocardiopsis sp. has been reported to be prolific in the production of secondary metabolites $[55,56]$ and recommended to contribute immensely to the chemical defense mechanisms of their host against predators with biologically active compounds and biofouling [57].

\section{The genus Brachybacterium}

The genus Brachybacterium is a Gram-positive, coccoid-to-ovoid shaped, non-motile bacteria. This genus was first proposed by [58] to belong to the family Dermabacteraceae, located in the Actinobacteria class. The genus Brachybacterium encompasses 10 recognized species, namely: Brachybacterium alimentarium, $B$. conglomeratum, B. faecium, B. fresconis, B. muris, B.nesterenkovii, B. paraconglomeratum, B. rhamnosum, $B$. sacelli, and $B$. tyrofermentans. These bacteria contain MK-7 as the major component of manaquinone and the polar lipid profile is composed of diphosphatidylglycerol, 
phosphatidylglycerol, and unidentified phospholipid and glycolipids [59]. Brachybacterium has been proved to be highly effective in removing manganese from solutions by converting it into insoluble manganese oxides. This bacterium did not only oxidize the manganese, but the resulting oxides themselves also absorbed the metal from the culture solution - thus making Brachybacterium sp. a potentially useful strain in bioremediation and cleaning up pollution. Also, this genus has been characterized as a cellulose-decomposing microorganism because of its unique attribute in converting a large amount of photosynthetically produced cellulosic materials into industrial substrates [60].

\section{Coagulation-Flocculation Technology in Wastewater Treatment}

This technology is usually employed in potable water and wastewater treatment to overcome the forces stabilizing the suspended particles, thereby facilitating the collision of particles and the formation of floc. Coagulation is a process whereby particle destabilization and charge neutralization occurs as a result of the addition of a positively charged ion of metal salt. On the other hand, flocculation refers to collision that occurs as a result of agitation that allows the particles to agglomerate into larger flocs. Land erosion, dissolution of minerals, and decaying of vegetation from domestic and industrial waste discharges have been responsible for suspended materials present in water and wastewater. Such materials may comprise dissolved organic and inorganic matters, and biological organisms such as bacteria, algae, or viruses. These materials must be removed or eliminated as they cause turbidity in water plus various health risks to people.

Most of the suspended materials or particles are smaller in size and they also carry negative charges in aqueous medium. As a result, to facilitate the process of settling, the particles have to come together to form larger flocs. However, this procedure is tedious as a result of electrostatic repulsion forces that hinder the particles from coming together coupled with the negative charge on the material. Therefore, it requires a longer time for settling and this problem can be solved by destabilizing the particles with the aid of a coagulant. Destabilization can be achieved either with one or a combination of two or more of the following mechanisms after the addition of a coagulant agent $[61,62]$ :

a) Compression of the electrostatic double layer.

b) Adsorption and charge neutralization.

c) Adsorption and inter particle bridging.

d) Enmeshment in precipitate using an excess coagulant dose.

Having destabilized the particles that are present in the wastewater, flocculation then facilitates the aggregation or conglomeration of flocs after the addition of an appropriate flocculating agent. Finally, particles must collide and this can take place under natural circumstances, (perikinetic floc formation), whereby aggregation is achieved by thermal motion of fluid molecules. It can also be achieved by dissipating mixing energy (orthokinetic floc formation) [62].

\section{The Flocculation Mechanism}

The concept of the flocculation mechanism has been classified into charge neutralization, electrostatic patch, and polymer bridging [63]. The flocculation mechanism for different types of flocculants and some of the examples of the mechanism are illustrated in Tables 3 and 4.

\section{Charge Neutralization}

This refers to the cancellation of negative charge when positively charged colloids or ions come in contact with a negative charge of a particle. Resultantly, electrostatic repulsion between the particles disappears and it enhances the process of coagulation. This also occurs when colloid particles and flocculants are of opposite charge. For instance, in a case where colloidal particles in industrial wastewaters are negatively charged, the use of inorganic flocculants and cationic polyelectrolytes are recommended [64].

Table 3. Flocculation Mechanism for Different Types of Flocculants.

\begin{tabular}{|c|c|c|}
\hline Flocculants category & Flocculants type & Flocculation mechanism \\
\hline Chemical coagulants & Inorganic metal salts & Charge neutralization \\
\hline \multirow{3}{*}{ Chemical flocculants } & $\begin{array}{c}\text { Polyelectrolytes with low MW and low CD } \\
\text { Poly electrolytes with high MW and low CD } \\
\text { Poly electrolytes with low MW and high CD } \\
\text { Polyelectrolytes with high MW and high CD }\end{array}$ & $\begin{array}{c}\text { Charge neutralization } \\
\text { Bridging } \\
\text { Electrostatic patch }\end{array}$ \\
\hline Bioflocculants & $\begin{array}{c}\text { Cationic chitosan } \\
\text { Anionic cellulose, tannin and sodium alginate } \\
\text { Anionic/neutral plant-based flocculants }\end{array}$ & $\begin{array}{c}\text { Charge neutralization }+ \text { bridging } \\
\text { Bridging } \\
\text { Bridging }\end{array}$ \\
\hline Grafted flocculants & Amphoteric/cationic/anionic graft copolymers & Charge neutralization + bridging \\
\hline
\end{tabular}

Source: [61] 
Table 4. Examples of Flocculation Mechanisms.

\begin{tabular}{|c|c|c|c|c|}
\hline Flocculant type & Flocculant characteristics & Flocculation medium & $\begin{array}{c}\text { Flocculation } \\
\text { mechanism }\end{array}$ & Reference \\
\hline $\begin{array}{l}\text { Quaternary ammonium based } \\
\text { derivative of polyacrylamide } \\
\text { (cationic) }\end{array}$ & $\begin{array}{l}\text { High MW }\left(16 \times 10^{6}\right) \\
\text { High CD }(100 \%)\end{array}$ & $\begin{array}{l}\text { Colloidal dispersion of } \\
\text { anionic polystyrene latex } \\
\text { particles }\end{array}$ & Bridging & {$[63]$} \\
\hline $\begin{array}{c}\text { Cationic polyacrylamide } \\
\text { (C-PAM) Polyethyleneimine } \\
\text { (cationic) } \\
\text { polyDADMAC (cationic) }\end{array}$ & $\begin{array}{c}\text { High MW, Low CD } \\
\text { Low MW, High CD } \\
\text { Medium,MW, Medium CD }\end{array}$ & $\begin{array}{l}\text { Suspension of calcium } \\
\text { carbonate }\end{array}$ & $\begin{array}{l}\text { Bridging Electrostatic } \\
\text { patch Charge } \\
\text { neutralization }\end{array}$ & {$[64]$} \\
\hline $\begin{array}{l}\text { Cationic copolymers of acrylamide/ } \\
\text { diallyldimethyl ammonium chloride }\end{array}$ & $\begin{array}{c}\text { Medium MW }\left(3 \times 10^{5}\right) \text {, } \\
\text { Low CD }(10 \%) \text { Medium } \\
\text { MW }\left(1.2 \times 10^{5}\right) \text {, Medium } \\
\text { CD }(40 \%) \text { Medium MW } \\
\left(1.2 \times 10^{5}\right), \text { High CD } \\
(100 \%)\end{array}$ & $\begin{array}{l}\text { Suspension of silica } \\
\text { particles }\end{array}$ & $\begin{array}{l}\text { Bridging Charge } \\
\text { neutralization }+ \\
\text { bridging/ bridging }\end{array}$ & {$[67]$} \\
\hline \multirow{2}{*}{ Cationic polyacrylamide (C-PAM) } & High MW, Low CD & \multirow{2}{*}{$\begin{array}{l}\text { Suspension of calcium } \\
\text { carbonate }\end{array}$} & Bridging & {$[68]$} \\
\hline & High MW, High CD & & Electrostatic patch & \\
\hline Cationic polyacrylamide (C-PAM) & $\begin{array}{l}\text { High MW }\left(7.2 \times 10^{6}\right), \text { High } \\
\text { CD }(80 \%) \text { High MW }(13 \times \\
\left.10^{6}\right), \text { Medium CD }(50 \%)\end{array}$ & $\begin{array}{l}\text { Suspension of calcium } \\
\text { carbonate }\end{array}$ & $\begin{array}{l}\text { Electrostatic patch }+ \\
\text { bridging bridging }\end{array}$ & {$[69]$} \\
\hline
\end{tabular}

\section{Electrostatic Patch Mechanism}

This involves charged polymers or colloids binding to a particle of the opposite charge. Particles attract each other through patches of opposite charges, causing coagulation of the suspension.

Flocculation can be induced by several methods. Metals such as alum and ferric chloride are commonly used coagulants. They usually dissociate in water and the metal ions can cause flocculation through the process of charge neutralization.

\section{Bridging}

This is a process whereby charged colloids come together to the surface of two different particles to form a bridge between the particles. This allows the particle to come together and is responsible for flocculation. High molecular-weight polymers with a low charge density adsorb on the surface in a way that long loops extend to the second surface. This allows polymers that are hanging to interact or attach together, thereby forming a bridge between the particles or colloids [65-67]. Polymer bridging has been reported as the mechanism for flocculation in treatment of textile wastewater with Plantago psyllium mucilage and Tamarindus indica mucilage $[68,69]$. The length of polymers is a major determining factor that activates proper bridging.

\section{Assessment of Flocculation Efficiency}

The addition of flocculants into a cylinder or flask results in the formation of an interface. The upper phase known as the supernatant contains the liquid while the sediments settle below the container. The Jar test and settling test are the parameters used in assessing flocculation efficiency.

\section{Jar Test}

This technique involves the addition of a flocculant to the solution at a dose that varies from $0.025 \mathrm{ppm}$ to $1 \mathrm{ppm}$. The working principle is achieved by stirring at a uniform speed. First, at a speed of $75 \mathrm{rpm}$ for 2 minutes and then at a slow speed of $25 \mathrm{rpm}$ for 5 minutes. Finally, a 10-minute settling time will be allowed before measuring turbidity of the supernatant using a turbidometer. In a situation where flocs are widely or evenly distributed, it is necessary to explore a higher velocity to suspended solids in order to obtain larger flocs.

\section{Settling Test}

In the case of a settling test, $100 \mathrm{ml}$ graduated measuring cylinder and a stopwatch is usually employed. This involves the addition of a suspension sample and the flocculants in the same cylinder. The cylinder is shaken properly to ensure thorough mixing. Thereafter, the measuring cylinder is positioned upright and the height of the interface between water and settled sediment is measured over time. The settling test has been proven to be more accurate in terms of accuracy than the jar test.

\section{Current Challenges and Future Direction}

Environmental pollution is a global problem. Water pollution caused by industrial pollutants is a public menace, making both private and government sectors 
interested in mitigating this problem. Coagulationflocculation technology is an important physicochemical step in the treatment of wastewater. This has been employed to eliminate or reduce suspended colloidal particles accountable for the presence of organic matter and turbidity in wastewater, which contributes to biological oxygen demand (BOD) and chemical oxygen demand (COD) content of the water [70]. At present, flocculants are prevalent in a variety of industrial processes such as wastewater treatment, drinking water purification, and the downstream process in fermentation [71].

Even though some flocculating agents have been established in removing various pollutants from wastewater in a laboratory scale, there is still a necessity to improve their efficiency in the removal of suspended colloids, particles, and other forms of organic and inorganic pollutants before the wastewater is discharged into the environment. Although chemically synthetic flocculants are playing dominant roles in waste and water treatment, they are nonbiodegradeable and toxic to the environment. Some of these synthetic flocculating substances have threatened public health and increased environmental risks. For example, polyacrylamide, one of the most popular flocculants, includes acrylamide monomers which are verified as both neurotoxins and strong carcinogens to human beings [72]. On the other hand, aluminum salts are by far the most widely used coagulants in water and wastewater treatment. However, several disadvantages of using aluminum salts - including Alzheimer's disease and similar health problems associated with residual aluminum in treated waters - have been identified [73].

A significant major global economic factor is that many developing countries can hardly afford the high costs of imported chemicals for water and wastewater treatment. As a result, they depend on inorganic and organic synthetic flocculants that are toxic and non-degradable [74]. The potential application of bioflocculants in the treatment of different wastewaters, decoulorization of dyewastewaters, cell removal, and biomass recovery has been well investigated and established [75, 14, 19]. However, in spite of all the bioflocculants recently identified and explored, none has been practically applied in industry because of poor productivity and exorbitant production costs [76]. Hence, it is desirable that other cost-effective, biodegradable, and environmentally friendly bioflocculants with strong flocculating activity are isolated and screened to supplement - if not replace - alum, ferric salts, and synthetic polymers. Many of the bioflocculants employed in flocculation have been used as pure culture. There is an urgent need to explore the interactions between actinobacteria microorganisms in a mixed culture to enhance better flocculating efficiency in the treatment of wastewater.

To date, the application and efficiency of screened actinobacteria in flocculation have yet to be validated, especially for large-scale medium production and wastewater treatment. Thus for the sake of producing actinobacteria in a large-scale medium coupled with better and higher efficiency in flocculation, the screening of actinobacteria has become a subject of paramount and urgent research in our laboratory.

\section{Acknowledgements}

We are grateful to the National Research Foundation (NRF) of South Africa for financial support.

\section{References}

1. PATIL S.V., PATIL C.D., SALUNKE B.K., RAHUL B., SALUNKHE R.B., BATHE G.A., PATIL D.M. Studies on Characterization of Bioflocculant Exopolysaccharide of Azotobacter indicus and its potential for wastewater treatment. Appl. Biochem. Biotechnol. 163, 463, 2011.

2. SHIH I.L., VAN Y.T., YEH L.C., LIN H.G., CHANG Y.N. Production of a biopolymer flocculant from Bacillus licheniformis and its flocculation properties. Bioresour. Technol. 78 (3), 267, 2001.

3. SINGH R.P., KARMAKAR G.P., RATH S.K., KARMAKAR N.C., PANDEY S.R., TRIPATHY T., PANDA J., KANAN K., JAIN S.K., LAN N.T. Biodegradable drag reducing agents and flocculants based on polysaccharides: Materials and Applications. Polym. Eng. Sci. 40, 46, 2000.

4. JANG J.H., IKE M., KIM S.M., FUJITA M. Production of a novel bioflocculant by fed- batch culture of Citrobacter sp. Biotechnol. Lett. 23, 593, 2001.

5. HOUGHTON J.I., QUARMBY J., STEPHENSON T. Municipal wastewater sludged waterability and the presence of microbial extracellular polymer. Water Sci.Technol. 44, 373, 2001.

6. KUMANI P., KUMAR S., YUVARAJ K.A., PAARI V., ARUL V. Production and purification of a novel exopolysaccharide from lactic acid bacterium Streptococcus phocae $\mathrm{P} 180$ and its functional characteristics activity invitro. Bioresour. Technol. 102, 4827, 2011.

7. SALEHIZADEH H., SHOJAOSADATI S.A. Extracellular biopolymeric flocculants: recent trends and biotechnological importance. Biotechnol. Adv. 19, 371, 2001.

8. SALEHIZADEH H., SHOJAOSADATI S.A. Removal of metal ions from aqueous solution by polysaccharide produced from Bacillus firmus. Water Res. 37, 4231, 2003.

9. ZHENG Y., YE Z., FANG X., LI Y., CIA W. Production and characteristics of a bioflocculant produced by Bacillus sp. F19. Biosour. Technol. 99, 7686, 2008.

10. GONG W., WANG S., SUN X., LIU X., YUE Q., GAO B. Bioflocculant production by culture of Serratia ficaria and its application in wastewater treatment. Bioresour. Technol. 99, 4668, 2008.

11. GOMMA E.Z. Production and characteristics of a heavy metal removing bioflocculant produced by Pseudomonas auroginosa. Polish J. Microbiol. 4, 281, 2012.

12. ZHANG Z., LIN B., XIA S., WANG X., YANG A. Production and application of a novel bioflocculant by multiple-microorganism consortia using brewery wastewater as carbon source. J. Environ. Sci. 19, 667, 2007.

13. ZHANG C., CUI Y., WANG Y. Bioflocculant produced from bacteria for decolorization, Cr removal and swine wastewater application. Sustain. Environ. Res. 22, 129, 2012.

14. COSA S., OKOH A. Bioflocculant production by a consortium of two bacterial species and its potential 
application in industrial wastewater and river water treatment. Pol. J. Environ. Stud. 23, 689, 2014.

15. ZHANG J., LIU Z., WANG S., JIANG P. Characterization of a bioflocculant produced by the marine myxobacterium Nannocystis sp. NU2. Appl. Microbiol. Biotech. 59, 517, 2002.

16. SHENG Y., ZHANG Q., SHENG Y., LI C., WANG H. Screening and flocculating properties of bioflocculantproducing microorganisms. Sci. Technol. 13, 289, 2006.

17. WAN C., ZHAO X.Q., GUO S.L., ASRAFUL ALAM M.D., BAI F.W. Bioflocculant production from Solibacillus silvestris W01 and its application in cost-effective harvest of marine microalga Nannochloropsis oceania by flocculation. Bioresour Technol. 135, 207, 2013.

18. ZHAO H., LIU H., ZHOU J. Characterization of a bioflocculant MBF-5 by Klebsiella pneumonia and its application in Acanthamoeba cysts removal. Bioresour Technol. 37, 226, 2013.

19. UGBENYEN A.M., COSA S., MABINYA L.V., OKOH A.I. Bioflocculant Production by Bacillus sp. Gilbert Isolated from a Marine Environment in South Africa. Applied Biochem Micro. 50 (1), 592014.

20. PENG L., YANG C., ZENG G., WANG L., DAI C., LONG Z. Characterization and application of bioflocculant produced by Rhodococcus erythropolis using sludge and livestock waste-water as a cheap culture media. Appl Microbial Biotechnol. 98, 6847, 2014.

21. SYAFALNI S., ABUSTAN I., ISMAIL N., KWAN T.S. Production of bioflocculant by Chryseomonas luteola and its application in dye water treatment. Mod Appl Sci. 6, 13, 2012.

22. ZHANGD.,HOUZ., WANG T. Study on Rhodopseudomonas sphaeroides as coal microbial flocculant. Adv Mater Res. 550, 1090, 2012.

23. SATHIYANARAYANAN G., SEGHAL KIRAN G., SELVIN J. Synthesis of silver nanoparticles by polysaccharide bioflocculant produced from marine Bacillus subtilis MSBN17. Colloids Surf B Biointerfaces. 102, 13, 2013.

24. RAVEENDRAN S., POULOSE A.C., YOSHIDA Y., MAEKAWA T., KUMAR D.S. Bacterial exopolysaccharide based nanoparticles for sustained drug delivery, cancer chemotheraphy and bioimaging. Carbohydr Polym. 9, 22, 2013.

25. MABINYA L.V., COSA S., NWODO U., OKOH A.I. Studies on bioflocculant Production by Arthrobacter sp. Raats, a freshwater bacteria isolated from Tyume River, South Africa. Int. J. Mol. Sci. 13, 1054, 2012.

26. SU X., SHEN X., DING L., YOKOTA A. Study on the flocculability of the Arthrobacter sp., an actinomycete resuscitated from the VBNC state. World J Microbial Biotechnol. 28, 91, 2012.

27. NTSALUBA L., NWODO U., MABINYA V., OKOH I. Studies on bioflocculant production by a mixed culture of Methylobacterium sp. Obi and Actinobacterium sp. Mayor. BMC. Biotechnol. 13, 62, 2013.

28. NWODO U.U., AGUNBIADE M.O., GREEN E., NWAMADI M., RUMBOLD K., OKOH A.I. Characterization of an exopolymeric flocculant produced by a Brachybacterium sp. Materials. 6, 1237, 2013.

29. NWODO U.U., AGUNBIADE M.O., GREEN E., MABINYA L.V, OKOH A.I. A Freshwater Streptomyces, isolated from Tyume River, produces a predominantly extracellular glycoprotein bioflocculant. Int. J. Mol. Sci.13, $8679,2012$.

30. SHIMOFURUYA H., KOIDE A., SHIROTA K., TSUJI T., NAKAMURA M., SUZUKI J. The production of flocculating substance(s) by Streptomyces griseus. Biosci. Biotechnol. Biochem; 60, 498, 1996.

31. MONA EM MABROUK. Production of bioflocculant by the marine actinomycete Nocardiopsis aegyptia $s p$. nov. Life Sci. Journal. 11 (12), 27, 2014.

32. SUH H., KWON H., LEE C.H., KIM H.S., OH H.M., YOON B.D. Characterization of bioflocculant produced by Bacillus sp. DP-152. J. Ferment. Bioeng. 84, 108, 1998.

33. WANG L., MA F., QU Y., SUN D., LI A., GUO J., GUO J., YU B. Characterization of a compound bioflocculant produced by mixed culture of Rhizobium radiobacter $\mathrm{F} 2$ and Bacillus sphaeicus F6. World J. Microbiol. Biotechnol. 10, 1007, 2011.

34. SI M.R., XUE Q.H., LAI H.X. Studies on selection of the isolation medium for actinomycetes and inhibition methods to miscellaneous microorganism. Microbiol. 33, 61, 2004.

35. LECHEVALIER M.P., LECHEVALIER H.A. The chemotaxonomy of Actinomycetes. In: A. Dietz and D.W. Thaye, Editors, Actinomycete Taxonomy: Society for Industrial Microbiology Special Publication No.6, Society for industrial Microbiology, Arlington, V.A. 227, 1980.

36. GOODFELLOW M. The actinomycetes I. Supragenic classification of actinomycetes. In: Williams S.T., Sharpe M.E., Holt J.G. (Eds.), Bergey's Manual of Systematic Bacteriology. Williams and Wilkins co., 2333, Baltimore 1989.

37. GARRITY G.M., WINTERS M., SEARLES D.B. Taxonomic outline of the somerise genera. In Bergeys Manual of Systematics Bacteriology. Springer-Verlag, New York, NY. 1 (2), 155, 2001.

38. PANDEY B., GHIMIRE P., AGRAWAL V.P. Studies on the antibacterial activity of the actinomycetes isolated from the Khumbu region of Nepal. Appl. Microbiol. 5, 235, 2008.

39. SULTAN M.Z., KHATUNE N.A., SATHI Z.S., BHUIYAN SAMD., SADIK G.M., CHOUDURY M.A., GAFUR M.A., RAHMAN AAMD. In vitro antibacterial activity of an active metabolite isolated from Streptomyces species. Biotechnol. 1, 100, 2002.

40. SIEFERT'T J.L., FOX G.E. Printed in Great Britain Phylogenetic mapping of bacterial morphology. 144, 2803, 1998.

41. VOBIS G. The prokaryotes: A handbook of the Biology of Bacteria: Ecophysiology, Isolation, Identification, Applications, Balows, A, Truper, HG, Dworkin M, and Harder W, Eds., New York: Springer. 2, 1029, 1992.

42. JIANG C., XU L. Diversity of Aquatic Actinomycetes in lakes of the Middle Plateau, Yunnan, China. J. Appl. Environ. Microbiol. 62 (1) 249, 1996

43. ZAITLIN B., WATSON S.B. Actinomycetes in relation to taste and odour in drinking water: Myths, tenets and truths. 40, 1741, 2006.

44. BRUNS A., PHILLIPP H., CYPIONKA H., BRINKHOFF T. Aeromicrobium marinum sp.nov, an abundant pelagic bacterium isolated from the German Wadden Sea. Int. J. Syst. Evol. Microbiol. 53 (3), 1917, 2003.

45. TERKINA I.A., DRUKKER V.V., PARFENOVA V.V., KOSTORNOVA Y.A. The biodiversity of actinomycetes in Lake Baikal. Microbiol. 71 (3), 346, 2002.

46. GOOD FELLOW M., WILLIAMS S.T. Ecology of Actinomycetes. Annu. Rev. Microbiol. 37, 189, 1983.

47. KÄMPFER P. "The Family Streptomycetaceae, Part I: Taxonomy". In Dworkin, Martin; Falkow, Stanley; Rosenberg, Eugene; Schleifer, Karl-Heinz; Stackebrandt, Erko. The Prokaryotes. pp. 538, 2006. doi:10.1007/0-38730743-5 22. ISBN 978-0-387-25493-7.

48. OMURA S. Genome sequence of an industrial 
microorganisms Streptomyces avermitilis: Deducing the ability of producing secondary metabolites. Proc. Natl. Acad. Sci. USA. 98, 12215, 2001.

49. KIESER T., BIBB M.J., BUTTNER M.J., CHATER K.F., HOPWOOD D.A. Practical Streptomyces Genetics (2nd ed.). Norwich, England. 2000.

50. ESCHBACH M., MÖBITZ H., ROMPF A., JAHN D. Members of the genus Arthrobacter grow anaerobically using nitrate ammonification and fermentative processes: Anaerobic adaptation of aerobic bacteria abundant in soil. FEMS Microbiol. Lett, 223, 227, 2003.

51. SHEN M., ZENG Y.G., SHEN Y.C. Isolation and characterization of a novel Arthrobacter nitroguajacolicus ZJUTB06-99, capable of converting acrylonitrile to acrylic acid. Process Biochem, 44, 781, 2009.

52. CAMARGO F.A.O., BENTO F.M., OKEKE B.C., FRANKENBERGER W.T. "Hexavalent chromium reduction by an actinomycete, Arthrobacter crystallopoietes ES 32". Biological Trace Element Research 97 (2), 183, 2003.

53. MEYER J. Genus Nocardiopsis, In S. T. Williams, M. E. Sharpe, and J. G. Holt (ed.), Bergey's Manual of Systematic Bacteriology, vol. 4. The Williams \& Wilkins Co., Baltimore, Md p. 2562-2568. 1989.

54. MONTALVO N.F., MOHAMED N.M., ENTICKNAP J.J., HILL R.T. Novel actinobacteria from marine sponges. Antonie Van Leeuwenhoek, 87, 29, 2005.

55. SELVIN J., SHANMUGHAPRIYA S., GANDHIMATHI R., SEGHAL K.G., RAJEETHA RAVJI T., NATARAJASEENIVASAN K., HEMA T.A. Optimization and production of novel antimicrobial agents from sponge associated marine actinomycetes Nocardiopsis dassonvillei MAD08 Appl. Microbiol. Biotechnol. 83, 435, 2009a.

56. COLLINS M.D., BROWN J., JONES D. Brachybacterium faecium gen. nov., sp. nov., a coryneform bacterium from poultry litter. Int. J. Syst. Bacteriol. 38, 45, 1988.

57. CHOU J.H., LIN K.Y., LIN M.C., SHEU S.Y., WEI Y.H., ARUN A.B., YOUNG C.C., CHEN W.M. Brachybacterium phenoliresistens sp. nov., isolated from oil contaminated coastal sand. Int. J. Syst. Evol. Microbiol. 57, 2674, 2007.

58. BOLTO B., GREGORY J. Organic polyelectrolytes in water treatment. Water Res. 41, $2301,2007$.

59. LEE C.S., ROBINSON J., FONG CHONG M. A review on application of flocculants in wastewater treatment. Process safety and Environmental protection http://dx.doi. org/10.1016/j.psep.2014.04.010 2014.

60. BIGGS S., HABGOOD M., JAMESON G.J., YAN Y.D. Aggregate structures formed via a bridging flocculation mechanism. Chem. Eng. J. 80, 13, 2000.

61. DUAN J., GREGORY J. Coagulation by hydrolyzing metal salts. Advances in Colloid and Interface Sci. 100, 475, 2003.

62. CRITTENDEN C.C., TRUSSEL R.R., HAND D.W., HOWE, K.J., TCHOBANOGLOUS G. Coagulation, mixing and flocculation, in: Water Treatment principles and Design, second ed., John Wiley and Sons, New Jersey, 643, 2005.

63. BLANCO A., FUENTE E., NEGRO C., TIJERO J. Flocculation monitoring: focused beam reflectance measurement as a measurement tool. Can. J. Chem. Eng. 80, $1,2002$.

64. LEE K.E., MORAD N., TENG T.T., POH B.T. Development, characterization and the application of hybrid materials in coagulation/flocculation of wastewater: a review. Chem. Eng. J. 203, 370, 2012.

65. MISHRA A., BAJPAI M. Flocculation behavior of model textile wastewater treated with a food grade polysaccharide. J. Hazard. Mater. 118 (1-3), 213, 2005.

66. MISHRA A., BAJPAI M. The flocculation performance of Tamarindus mucilage in relation to removal of vat and direct dyes. Bioresour. Technol. 97 (8), 1055, 2006.

67. ZHOU Y., FRANKS G.V. Flocculation mechanism induced by cationic polymers investigated by light scattering. Langmuir. 22, 6775, 2006.

68. RASTEIRO M.G., GARCIA F.A.P., DEL MAR PÉREZ M. Applying LDS to monitor flocculation in papermaking. Part. Sci. Technol. 25, 303, 2007.

69. RASTEIRO M.G., GARCIA F.A.P., FERREIRA P., BLANCO A., NEGRO C., ANTUNES E. The use of LDS as a tool to evaluate flocculation mechanisms. Chem. Eng. Process. 47, 1323, 2008.

70. SARKAR B., CHAKRABARTI P.P., VIJAYKUMAR A., KALE V. Wastewater treatment in dairy industriespossibility of reuse. Desalination, 195, 141, 2006.

71. SHIH I.L., VAN Y.T., YEH L.C., LIN H.G., CHANG Y.N. Production of a biopolymer flocculant from Bacillus licheniformis and its flocculation properties. Bioresour. Technol. 78 (3), 267, 2001.

72. HE J., ZOU J., SHAO Z., ZHANG J., LIU Z., YU Z. Characteristics and flocculating mechanism of a novel bioflocculant HBF-3 produced by deep-sea bacterium mutant Halomonas sp. V3a'. World J. Microbiol. Biotechnol. 26, 1135, 2010.

73. BANKS W.A., NIEHOFF M.L., DRAGO D., ZATTA P. Aluminum complexing enhances amyloid protein penetration of blood-brain barrier. Brain Res. 1116, 215, 2006.

74. NDABIGENGESERE A., NARASIAH K. S. Quality of water treated by coagulation using Moringa oleifera seeds. Water. Resourc. 32, 781, 1998.

75. KIM D.G., LA H.J., AHN C.Y., PARK Y.H., OH H.M. Harvest of Scenedesmus sp. with bioflocculant and reuse of culture medium for subsequent high-density cultures. Bioresour Technol. 102, 3163, 2011.

76. HE J., ZHEN Q., QIU N., LIU Z., WANG B., SHAO Z., YU Z. Medium optimization for the production of a novel bioflocculant from Halomonas sp. V3a' using response surface methodology. Bioresour. Technol. 100, 5922, 2009. 